\section{Prescience and Conscience: Leó Szilárd (1898-1964)}

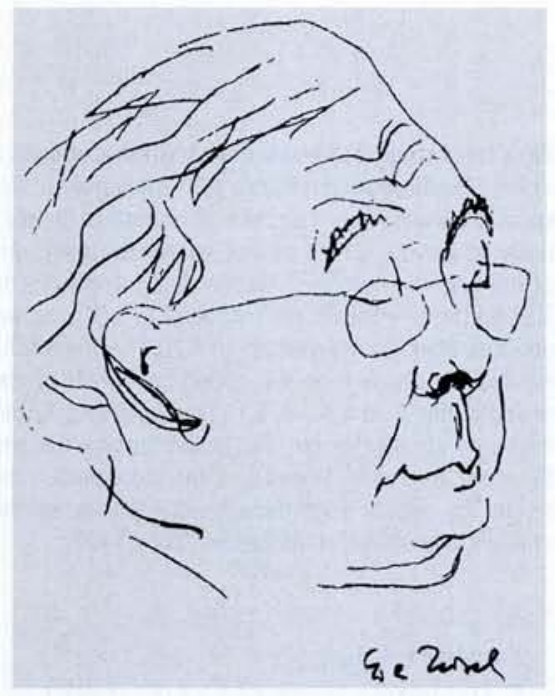

On 11 February the remains of Leó Szilárd were laid to rest in his native Budapest, after a commemorative seminar and other ceremonies, writes Denis Weaire.

Szilárd was born in 1898 and died in the USA in 1964. His extraordinary career cannot be adequately summarised here. As George Marx, President of the Hungarian Physical Society, tells it, the experience of growing up in the rich intercultural soup of Budapest during the turbulent years around the time of the First World War created in him a restless, ironic and irascible personality. He was an "intellectual bumble-bee" who never settled down in later life, but carried his genius constantly from one place to another, staying mostly in hotels.

He was the first to conceive the nuclear chain reaction and was involved in its eventual realisation in Chicago. Thereafter he was a constant advocate of nuclear arms control, particularly through the Pugwash movement. In this way, having experienced conflict and prejudice in his youth, Szilárd devoted himself to healing the world's wounds and averting its destruction. Few physicists have shown the same combination of prescience and conscience. stood. lamp."' questions put to rabbis. Szilárd's friend in Berlin during the 1920 s, the chemist Herrnann Mark, remembered this as one of Szilárd's favourite jokes. Two Jewish boys could not resolve a dispute and called on their rabbi for help. He was dining with his wife, but agreed to hear them, and the first boy explained his side of the argument.

"You know," said the rabbi, "I think you're right." Then the second boy stated the opposite position.

"You know," said the rabbi, "I think you're right." At this the rabbi's wife interrupted.

"You can't do that," she complained.

"Leó loved jokes," recalled the chemist Leslie Orgel, his colleague at the Salk Institute for Biological Studies. "Humour for Leó revealed a higher nature and a different truth," Orgel said. In this talk I will describe how Leó Szilárd used wit to understand a threatening world - and to undermine it. Szilárd's wit was one of his most creative powers, often fondly remembered, but also at times misunder-

The joke that Orgel best remembered was one of Szilárd's favourites: about Diogenes, the ancient Greek philosopher known to wander about in the daylight with a lamp, "looking for an honest man." As Szilárd told it, Diogenes comes back to Earth and reappears in Athens, where he is again seen walking the streets, lamp in hand, again "looking for an honest man." $\mathrm{He}$ is clearly unsuccessful there because soon Diogenes is seen walking with his lamp in Rome. Next he appears in Paris, still walking with his lamp and "looking for an honest man." Finally Diogenes comes to Budapest, where someone recognizes him and asks, "Diogenes, what are you doing wandering the streets?" And Diogones answers: "I'm looking for my

Also while at the Salk Institute, Szilárd told Jonas Salk that there are three stages to scientific truth. Confront scientists with a new idea, Szilárd said, and most will reply: "It's not true!" Next they'll say: "If true, it's not very important!" Finally, they'll say: "We knew it all along!"

Szilárd had learned from his frequent conversations with Albert Einstein that relativity applies not only to physics but also to life. The two physicists often discussed philosophy, cosmology, and the means to discover God's truth. Truth itself, they agreed, could be relative, subtle, and ironic. And seeking truth could also be funny. Szilárd, like many young men from Jewish families in the Austro-Hungarian culture, relished telling clever jokes about
"You can't tell one boy he's right, then tell the other he's right."

The rabbi paused, and thought. "You know," he told his wife, "I think you're also right."

Szilárd's wit could be both comic and cosmic, as it was when he contemplated the origins of Homo sapiens and sion at the University of Chicago, Manhattan Project scientists led by physicist Enrico Fermi speculated that life had probably evolved elsewhere in the universe. Fermi even thought it likely that extraterrestrial creatures "should have arrived here by now," and asked, "so where are they?" "They are among us," Szilárd declared, "but they call themselves Hungarians."

Szilárd liked jokes about being Hungarian, and once told historian Max Lemer that Martians had come to Earth in a space ship and left only their stupidest ones behind Hungarians like Szilárd and Wigner and Von Neumann. Szilárd was also amused when a New York socialite proclaimed him an "honourary mortal."

But Szilárd's humourous view of cosmology turned grimmer one afternoon at Rockefeller University in the 1950s, during a discussion with information theorist Norbert Wiener about the origins of life. To the question, "given many planets like Earth, would man emerge on one of them?" Szilárd answered: "No!" Why not? Because, Szilárd said, “God wouldn't make the same mistake twice!"

Indeed, Szilárd's wit could be deadly serious when he used it to confront such topics as the nuclear arms race or ColdWar paranoia. For years Szilárd struggled to devise methods to help the United States and the Soviet Union end their insane nuclear arms race, and when his ideas were ignored as serious proposals, he put them in comic disguise. "If they Hungarians. During a brainstorming ses- 
cannot take it straight," Szilárd vowed, "they will get it in fiction." Thus, in 1960, he wrote a comic parable of future history, The Voice of the Dolphins, that described how the US-Soviet nuclear arms race might finally end in the 1980 s. Szilárd's parable also included his long-held idea that the most practical way to persuade public officials to behave responsibly is simply to bribe them. "The book is not about the intelligence of the dolphin," Szilárd would say later, "but about the stupidity of man." Yet it contained jolly and affectionate examples of human reason.

On other occasions Szilárd used his wit to deal with personal fears. In "The Mark Gable Foundation," a 1948 science-fiction piece that later appeared in The Voice of the Dolphins and Other Stories, Szilárd confronted his own mortality. A clever biologist in the story (much like Szilárd himself) is about to be preserved cryogenically for 300 years. But on the night before his treatment, the biologist feels odd about his farewell meeting with a few friends. "Most of them seemed to have the feeling that they were sort of attending my funeral, since they would not see me again alive; whereas to me it seemed that it was I who was attending their funeral, since none of them would be alive when I woke up."

At Memorial Hospital in New York, in 1960, as Szilárd was directing his own treatment for bladder cancer, he made light of his possible death by recounting to a television interviewer a story about a man with heart trouble who visits his doctor. Said Szilárd: "And the doctor told him that he could live out his normal life expectancy if he were willing to go slow and to restrict his activities. The man thought this over - and finally, he told his doctor that he is not going to slow down. 'You see, Doctor,' he said, 'if worst comes to the worst, I'll be dead ten years longer.' This, I think, is a healthy attitude to take towards life and towards death." (Szilárd's story was prophetic because after recovering from bladder cancer, he did not restrict his activities, and four years later died from a heart attack.)

Humour could help Szilárd to confront his professional fears as well. At the University of Chicago, on the night of 1 December 1942, the physiological psychologist Heinrich Kluver invited Szilárd to dinner. Kluver didn't know it, but on the campus, in just a few hours, Manhattan Project scientists had planned a top-secret experiment to create the world's first selfsustaining nuclear chain reaction-using a reactor co-designed by Fermi and Szilárd. On their walk to the restaurant Kluver was puzzled when Szilárd announced that this would be his second dinner that night. Szilárd said he was eating it "just in case."

"Just in case what?" Kluver wondered.

"In case an important experiment doesn't succeed," said Szilárd with his typical air of mystery. Trying not to reveal their secret plans, Szilárd said only that he and other scientists knew something they had built "might just fail to work; indeed, that seems to be the most likely outcome." However, Szilárd said that another more remote possibility prompted his second meal. You see, he explained, if their experiment "works too well" there might be an explosion.

But did Szilárd distrust the conclusions of his own colleagues? asked Kluver.

"Not at all," said Szilárd, who, as we know, loved to eat. "But even the greatest theoretical physicists cannot be absolutely certain. So I felt that a second dinner was in order."

Szilárd also loved riddles and paradoxes. When studying in Berlin in the 1920s, Szilárd asked his brother, Bela, "What is an optimist?" and then answered: "One who thinks that the future is uncertain."

During his years in Berlin, Szilárd enjoyed long and discursive walks with compatriot Eugene Wigner, and the two young men often disagreed about math and science and human nature. Szilárd praised applied reason on one walk while Wigner questioned this faith in the powers of the mind "You are a pessimist, Wigner," Szilárd declared.

"But," replied Wigner, "am I not usually right?"

"It is hard to be right and be a pessimist," Szilárd concluded.

"Leó Szilárd was a very complex personality," said his friend and fellow physicist, the Nobel laureate Hans Bethe. "He was one of the most intelligent people I have ever known. His mind worked quickly and profoundly, and he was able to come to ideas that most of us appreciated only after many hours of talk. This was his strength and, of course, also his weakness. He was always ahead of his time. His ideas often were expressed in paradoxes, and the paradoxes were not always understood."

Sometimes Szilárd's wit puzzled even Szilárd. He aimed to make his jokes "slightly malicious without being outright offensive" but admitted that at times he wasn't sure whether he was being serious or silly. In 1954, when physicist J. Robert
Oppenheimer was accused by his political enemies of posing a threat to national security, Szilárd retaliated by writing "Security Risk," a political satire that mocked anti-Communist paranoia. At the time, US diplomats were threatened with blackmail for being homosexuals, and Szilárd wrote himself into the story as giving a perfectly rational solution to the State Department: "Simply publish once a month a list of known homosexuals on your payroll," for "clearly those whose names have been made public can no longer be blackmailed." But the satire's narrator confessed that "with Szilárd, I never know when he is serious and when he is joking, and I suspect that often he does not know him- continued on page 123

Leó Szilárd Biography

1898 Born, 11 February, Budapest

1919 Left Hungary to escape anti-Semitism

1922 Doctorate, University of Berlin

1929 Published his classic analysis of Maxwell's Demon, in which he showed that an entropy of a unit of information is equal to $k \ln 2$

1933 Fled Germany to escape Nazism

1938 Moved to New York City

1939 On learning of the discovery of fission, predicted that uranium would sustain a chain reaction. Drafted Einstein's letter to US President Roosevelt warning of the possibility of an atomic bomb

1946 Appointed Professor of Biophysics, University of Chicago

1957 Began participation in Pugwash conferences

1960 Met Soviet Premier Khrushchev. Proposed Washington-Moscow "hotline"

1962 Flew to Switzerland during the Cuban Missile Crisis

1964 Died, 30 May

source

www.peak.org/ danneng/chronbio.html 